\title{
PENERAPAN MODEL PEMBELAJARAN PROBLEM BASED LEARNING (PBL) UNTUK MENINGKATKAN HASIL BELAJAR GEOGRAFI KELAS XI IPS 1 SMA NEGERI 12 MAKASSAR.
}

\author{
Baiatun Nisaa Nur ${ }^{1}$ \\ ${ }^{1}$ PROGRAM STUDI PENDIDIKAN GEOGRAFI / JURUSAN GEOGRAFI / \\ FAKULTAS MATEMATIKA DAN ILMU PENGETAHUAN ALAM / \\ UNIVERSITAS NEGERI MAKASSAR \\ Email : sriwulangdari@gmail.com
}

\begin{abstract}
The results showed an increase in the geography learning outcomes of XI IPS 1 students at Makassar State High School 12 after the problem based learning model was applied with the following indications: 1) the learning value of the geography of students in which $71.34 \%$ experienced a learning model of learning problems improvement after applied problem based learning models in the first cycle of $73.81 \%$ including the medium category and the second cycle $79.01 \%$ including the high category, with an increase in the percentage of $6.58 \%, 2)$ the results of observations of student activities in teaching and learning activities experienced changes, at cycle I 46.7\% experienced changes in student learning activities in the second cycle $59.4 \%$ with the active category. This means experiencing improved attitude from the previous cycle. It is recommended: 1) geography teachers should be creative in creating a classroom atmosphere so that students are not bored and comfortable in presenting material while learning and are more motivated in paying attention to what is taught, 2) it is best for the school to maximize facilities and infrastructure in schools, provide textbooks in library.
\end{abstract}

Keywords: Problem Based Learning, Geography Learning Outcomes, Students

\section{ABSTRAK}

Hasil Penelitian menunjukkan hasil belajar geografi siswa kelas XI IPS 1 SMA Negeri 12 Makassar mengalami peningkatan setelah diterapkan Model problem based learning dengan indikasi sebagai berikut: 1) nilai rerata belajar hasil geografi siswa siswa dimana sebelum menggunakan model pembelajaran problem based learning 71,34\% mengalami peningkatan setelah diterapkan model problem based learning pada siklus I 73,81\% termasuk kategori sedang dan siklus II 79,01\% termasuk kategori tinggi, dengan persentase peningkatan 6,58\%, 2) hasil observasi aktivitas siswa dalam kegiatan belajar mengajar mengalami perubahan, pada siklus I 46,7\% mengalami perubahan aktivitas belajar siswa pada siklus II 59,4\% dengan kategori aktif. Hal ini 
email: lageografia@unm.ac.id

Jurusan Geografi Fakultas Matematika dan Ilmu Pengetahuan Alam

Universitas Negeri Makassar Sulawesi Selatan, Indonesia

Nisaa, Baiatun, 2017, Penerapan Model Pembelajaran Problem Based Learning (Pbl) Untuk Meningkatkan Hasil Belajar Geografi Kelas XI Ips 1 SMA Negeri 12 Makassar.

berarti mengalami perbaikan sikap dari siklus sebelumnya. Disarankan: 1) guru geografi sebaiknya kreatif dalam menciptakan suasana kelas agar siswa tidak bosan dan nyaman dalam penyajian materi pada saat belajar serta lebih termotivasi dalam memperhatikan apa yang diajarkan,2) sebaiknya kepada pihak sekolah memaksimalkan sarana dan prasarana di sekolah, menyediakan buku ajar di perpustakaan.

Kata Kunci: Problem Based Learning, Hasil Belajar Geografi, Siswa

\section{PENDAHULUAN}

Pendidikan merupakan suatu keharusan yang tidak bisa di elakkan, karena di era globalisasi saat ini, arus informasi menerpakan semua lapisan kehidupan menuntut usaha pengembangan sumber daya manusia dengan segala dimensinya baik dibidang pengetahuan, nilai dan sikap, maupun keterampilan. Pengembangan yang dilandasi kemampuan intelektual, kecerdasan emosional dan kreativitas yang hanya dapat dilakukan melalui pendidikan. Artinya pendidikan mempunyai peranan yang amat strategis untuk mempersiapkan generasi muda yang memiliki keberdayaan, kecerdasan emosional yang tinggi dan menguasai mega skill yang mantap (Syahril, 2008).

Guru sangat berperan penting dalam mengembangkan pengetahuan dan mengikuti perkembangan jaman di era globalisasi ini dengan teknologi yang semakin canggih. Sebab semakin berkembangnya jaman peserta didik akan lebih kritis dengan pengetahuan yang mereka temukan di luar sana. Seorang guru juga harus senantiasa memberikan kenyamanan kepada peserta didik agar peserta didik merasa senang ketika belajar atau ketika berada di kelas. Untuk mewujudkan hal tersebut pemerintah tidak tinggal diam, berbagai upaya telah ditempuh untuk meningkatkan kualitas pembelajaran agar menghasilkan peserta didik sebagai masa depan bangsa yang siap memberikan sumbangsi untuk kemajuan Republik Indonesia dimasa yang akan datang upaya itu, antara lain: pembaharuan dalam kurikulum, pengembangan model dan metode pembelajaran, perubahan sistem penilaian, dan lain sebagainya.

Maka dari itu keberhasilan dalam proses pembelajaran khususnya mata pelajaran geografi juga tidak terlepas dari kesiapan peserta didik dan kesiapan pengajar (guru). Peserta didik dituntut mempunyai minat terhadap pelajaran geografi. Demikian juga pengajar dituntut mengusai materi yang akan diajarkan serta mampu memilih model pembelajaran yang tepat sehingga akan tercipta interaksi edukatif yang baik menuju kearah peningkatan prestasi belajar peserta didik karena hingga saat ini prestasi belajar peserta didik terhadap pembelajaran geografi dianggap masih rendah, padahal geografi sebagai salah satu cabang ilmu pengetahuan memiliki peranan penting dalam meningkatkan penguasaan ilmu pengetahuan dan teknologi. Geografi sebagai salah satu ilmu pengetahuan yang mempelajari gejala alam dan kehidupan di muka bumi serta interaksi antara manusia dengan lingkungan tentunya banyak membahas fenomena dan masalah-masalah yang terjadi dalam kehidupan sehari-hari. Untuk menyelesaikan atau memecahkan setiap masalah tersebut tentunya harus menggunakan model yang tepat dalam setiap pembelajaran.

Salah satu komponen penting dalam pendidikan adalah kurikulum. Indonesia memiliki kurikulum yang dibuat sebagai pegangan guru dalam melaksanakan tugasnya sebagai pendidik didalam kelas. Kurikulum di Indonesia sendiri telah mengakami perkembangan dari periode ke periode. Perubahan ini tentu saja berdasarkan pada perkembangan ilmu pengetahuan dan teknologi secara global serta kebutuhan kegiatan proses belajar mengajar akan perkembangan 
email: lageografia@unm.ac.id

Jurusan Geografi Fakultas Matematika dan Ilmu Pengetahuan Alam

Universitas Negeri Makassar Sulawesi Selatan, Indonesia

Nisaa, Baiatun, 2017, Penerapan Model Pembelajaran Problem Based Learning (Pbl) Untuk Meningkatkan Hasil Belajar Geografi Kelas XI Ips 1 SMA Negeri 12 Makassar.

pedoman pembelajaran. Setelah penerapan KTSP dianggap sudah tidak menjadi jalan keluar bagi pendidikan saat ini, Kurikulum 2013 mulai diterapkan dalam pendidikan Indonesia.

Peneliti juga melakukan wawancara lanjutan terhadap guru geografi yang mengajar di SMA Negeri 12 Makassar, dan diperoleh keterangan bahwa pada saat proses pembelajaran berlangsung peserta didik dapat mengerti tentang penjelasan guru namun ketika diberikan soal dan pertanyaan serupa dengan materi saat itu, peserta didik selalu kesulitan untuk menjawab soal tersebut dan peserta didik masih menghafalkan materi pelajaran. Keterlibatan peserta didik dalam proses belajar itu sendiri masih kurang karena model mengajar yang digunakan konvensional (di ruang kelas peserta didik diam, dengar dan catat) sehingga tidak mengherankan jika masih banyak (60\%) peserta didik yang tidak mengetahui kriteria ketuntasan minimal yang di tetapkan oleh sekolah yakni 75 .

Ditinjau dari proses pelaksanaan pembelajaran, terindikasi bahwa guru masih belum mampu mengoptimalkan pengalaman peserta didik untuk membangun pemahaman mereka, sebab guru mengajarkan dengan cara mentransfer pengetahuan secara langsung. Hasil belajar yang terjadi di SMA Negeri 12 Makassar sebagaimana dijelaskan sebelumnya, masih jauh dari kata efektif. Sementara kegiatan pembelajaran yang di inginkan dalam dalam kurikulum di Indonesia adalah proses belajar yang aktif, kreatif, efektif, dan menyenangkan. Sehingga dengan melihat kondisi tersebut, peneliti berisiniatif untuk melakukan Penerapan Model Pembelajaran Problem Based Learning (PBL) untuk Meningkatkan Hasil Belajar Geografi Kelas XI IPS 1 SMA Negeri 12 Makassar.

\section{METODE PENELITIAN}

Penelitian ini merupakan penelitian tindakan kelas (Classroom Action Research) yang bersifat deskriptif sebab menggambarkan bagaimana suatu metode pembelajaran diterapkan dan bagaimana hasil yang diinginkan dapat dicapai. Tahap-tahap pelaksanaan dalam penelitian tindakan kelas meliputi perencanaan (planning), tindakan (action), pengamatan (observation), dan refleksi (reflection) yang dirangkai dalam satu siklus kegiatan (Sanjaya, 2011)

SMA Negeri 12 Makassar adalah sebuah sekolah yang terletak disebelah Timur Kota Makassar. Tepatnya di kelurahan Antang, Kecematan Manggala, di Jalan Moha Lasoro No. 57 Antang-Makassar kode pos 90234 dengan letak astronomis $05^{\circ} 09^{\prime} 48,103^{\prime \prime}$ LS dan $119^{\circ} 29^{\prime} 00.622^{\prime \prime}$ BT. Subjek penelitian ini adalah siswa kelas XI IPS 1 semester ganjil SMA Negeri 12 Makassar dengan jumlah 35 siswa.

Prosedur penelitian tindakan kelas ini direncanakan terdiri dari dua siklus, tiap siklus dilaksanakan sesuai dengan perubahan yang ingin dicapai, seperti apa yang didesain dalam faktor yang diselidiki, untuk melihat sejauh mana pemahaman siswa pada materi sumber daya kependudukan. Adapun pelaksanaan tindakan tersebut mengukuti prosedur penelitian tindakan kelas yaitu: (1) perencanaan, (2) pelaksanaan tindakan, (3) observasi dan evaluasi, (4) refleksi dalam setiap siklus.

Pengumpulan data didasarkan pada suatu metode atau prosedur agar data yang diinginkan dapat dikumpulkan secara lengkap dan teknik pengumpulan data pada penelitian ini adalah sebagai berikut: Teknik pengumpulan data yang digunakan dalam penelitian ini adalah sebagai berikut:

a. Data Obeservasi

Observasi aktivitas kelas, pengamatan langsung terhadap para siswa dengan memperhatikan tingkah laku dan mencatatnya pada lembar observasi.

b. Tes 
ISSN:1412-8187

email: lageografia@unm.ac.id

Jurusan Geografi Fakultas Matematika dan Ilmu Pengetahuan Alam

Universitas Negeri Makassar Sulawesi Selatan, Indonesia

Nisaa, Baiatun, 2017, Penerapan Model Pembelajaran Problem Based Learning (Pbl) Untuk Meningkatkan Hasil Belajar Geografi Kelas XI Ips 1 SMA Negeri 12 Makassar.

Jenis data penelitian adalah data kuantitatif berupa hasil tes yang diberikan kepada siswa dimaksudkan untuk mengetahui sejauh manakah suatu proses pembelajaran telah berlangsung sebagaimana yang di rencanakan setelah mengikuti pembelajaran dengan menggunakan model Problem based learning. Tes yang diberikan berupa soal pilihan ganda yang terdiri dari 30 nomor yang diberikan setiap akhir pertemuan setiap siklus.

c. Dokumentasi

Dokumentasi dimaksudkan suatu teknik yang digunakan untuk menghimpun dan menganalisis dokumen-dokumen, baik dokumen tertulis maupun dokumen elektronik seperti foto hasil kegiatan dan gambar dari sekolah.

Teknik analisis data yang digunakan untuk setiap komponen instrument penelitian ini adalah sebagai berikut:

a. Lembar Observasi Aktivitas Siswa

Aktivitas siswa selama proses belajar mengajar berlangsung dianalisis secara kualitatif berdasarlan aspek yang telah ditentukan. Kriteria penilaian yang digunakan untuk menentukan tingkat keberhasilan dalam penilaian mengacuh pada teknik karegorisasi keaktifan belajar menurut Nurhadi (2008) dalam Arfa (2014) dengan rumus:

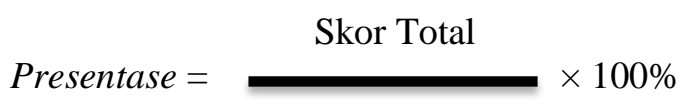

Skor Maksimal

Tabel 3.1 Penilaian Aktivitas Belajar

\begin{tabular}{cc}
\hline Kategori & Interval \\
\hline Kurang Aktif & $<25 \%$ \\
Cukup Aktif & $25 \%-50 \%$ \\
Aktif & $51 \%-74 \%$ \\
Sangat Aktif & $\geq 75 \%$ \\
\hline
\end{tabular}

Sumber: Nurhadi, (2008) dalam Arfa, (2014)

b. Hasil Belajar Siswa

Analisis Data yang digunakan untuk mengukur hasil belajar geografi menggunakan analisis deskriftif kuantitatif dari hasil persentase ketuntasan belajar secara perorangan dan nilai persentase peningkatan hasil belajar siswa dari siklus I ke siklus II.

Untuk menghitung persentase ketuntasan belajar secara perorangan digunakan rumus:

Nilai perolehan siswa $=\underset{\text { Skor maksimum }}{\text { Perolehan skor }} \times 100 \%$

Sumber: Arikunto, (2006) dalam Arfa (2014)

Hasil perolehan nilai siswa yang dianalisis kemudian diurutkan dengan kategori sebagai berikut:

Tabel 3.2 Hasil Belajar

Nilai kategori Kriteria


ISSN:1412-8187

email: lageografia@unm.ac.id

Jurusan Geografi Fakultas Matematika dan Ilmu Pengetahuan Alam

Universitas Negeri Makassar Sulawesi Selatan, Indonesia

Nisaa, Baiatun, 2017, Penerapan Model Pembelajaran Problem Based Learning (Pbl) Untuk Meningkatkan Hasil Belajar Geografi Kelas XI Ips 1 SMA Negeri 12 Makassar.

\begin{tabular}{cc}
\hline$<55$ & Sangat Rendah \\
$55-59$ & Rendah \\
$60-75$ & Sedang \\
$76-85$ & Tinggi \\
$86-100$ & Sangat Tinggi \\
\hline
\end{tabular}

Sumber: Amirullah, (2009) dalam Arfa (2014)

Untuk menghitung nilai presentase peningkatan hasil belajar siswa, maka digunakan rumus:

Skor setelah - Skor sebelum

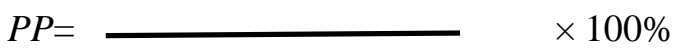

\section{Skor Setelah}

Adapun data hasil ketuntasan belajar individual siswa yang dapat dikategorikan dalam kriteria ketuntasan minimal yang digunakan untuk mata pelajaran geografi di SMA Negeri 12 Makassar sebagai berikut:

Tabel 3.3 Kriteria Ketuntasan Minimal (KKM)

\begin{tabular}{cc}
\hline Nilai & Kriteria \\
\hline$\geq 75$ & Tuntas \\
$<75$ & Tidak Tuntas \\
\hline
\end{tabular}

Sumber: SMA Negeri 12 Makassar

Adapun rumus yang dipergunakan untuk menentukan ketuntasan klasikal adalah sebagai berikut:

$$
\mathrm{PK}=\frac{\mathrm{ST}}{\mathrm{N}} \times 100 \%
$$

Sumber: Arikunto, (2006) dalam Arfa (2014)

\section{Hasil}

\section{HASIL DAN PEMBAHASAN}

Bagian ini akan dibahas hasil penelitian mengenai hasil belajar siswa dengan menggunakan teknik analisis data. Adapun yang akan dianalisis adalah pretes (nilai tengah semester) sebagai skor dasar, kemudian hasil tes akhir siklus I dan siklus II serta data aktivitas berupa lembar aktivitas siswa yang amati oleh observer untuk mengetahui tanggapan setelah penerapan model problem based learning.

Hasil yang diperoleh dari penelitian ini dianalisis secara kuantitatif dan kualitatif. Analisis kuantitatif digunakan untuk menganalisis nilai hasil belajar siswa dan analisis kualitatif digunakan untuk menganalisis data perubahan aktivitas siswa berupa lembar observasi.

Hasil penelitian yang diperoleh melalui tes hasil belajar menunjukkan kemampuan siswa dalam memahami materi pelajaran, baik sebelum diterapkan model problem based learning (nilai hasil belajar tengan semester) maupun setelah penerapan model problem based learning dengan memberikan diskusi pada siklus I dan siklus II. 
ISSN:1412-8187

email: lageografia@unm.ac.id

Jurusan Geografi Fakultas Matematika dan Ilmu Pengetahuan Alam

Universitas Negeri Makassar Sulawesi Selatan, Indonesia

Nisaa, Baiatun, 2017, Penerapan Model Pembelajaran Problem Based Learning (Pbl) Untuk Meningkatkan Hasil Belajar Geografi Kelas XI Ips 1 SMA Negeri 12 Makassar.

\section{Pretes (nilai tengah semester)}

Hasil belajar siswa kelas XI IPS1 SMA Negeri 12 Makassar pada materi sumber daya kependudukan sebelum menerapkan model pembelajaran PBL dapat diamati melalui tabel berikut:

Tabel 4.1 Distribusi Nilai Belajar siswa Pretes

\begin{tabular}{cc}
\hline Data Penelitian & Nilai Statistik \\
\hline Subjek & 35 \\
Skor Ideal & 100 \\
Nilai Terendah & 60 \\
Nilai Tertinggi & 80 \\
Rentang Skor & 20 \\
Rata-rata Skor & 71,34
\end{tabular}

Sumber: Hasil Olahan Data, 2017

Tabel 4.1 diatas menunjukkan distribusi nilai hasil belajar siswa pretes bahwa dari subjek yang berjumlah 35 siswa untuk berhasil belajar pada tengah semester sebelum menggunakan model problem based learning (pretes) dengan skor ideal yang mungkin dapat dicapai 100 dimana tersebar dari nilai tertinggi 80 dan nilai terendah 60 dengan rentang skor 20. Karena rentang skor mencapai 20 berarti nilai yang didapat siswa hampir sama serta nilai rata-rata $71.34 \%$.

Selanjutnya Tabel 4.2 dikonvensikan kedalam tabel distribusi frekuensi dan persentase yang dapat dilihat pada tabel berikut ini:

Tabel 4.2 Ditribusi Frekuensi dan Persentase Kategori Nilai Hasil Belajar Siswa Pretes

\begin{tabular}{cccc}
\hline Skor & Kategori & frekuensi & Persentase \\
\hline$<55$ & Sangat Rendah & 0 & 0 \\
$55-59$ & Rendah & 0 & 0 \\
$60-75$ & Sedang & 27 & $75 \%$ \\
$76-85$ & Tinggi & 8 & $22,2 \%$ \\
$86-100$ & Sangat Tinggi & 0 & 0 \\
\hline & & $\mathbf{3 5}$ & $\mathbf{1 0 0 \%}$ \\
\hline
\end{tabular}

Sumber: Hasil Olahan Data, 2017

Hasil analisis deskriftif tabel 4.2 menunjukkan bahwa dari 35 siswa yang menjadi subjek, jika dikelompokkan dalam lima kategori maka ditemukan 27 siswa atau $75 \%$ pada kategori "sedang". 8 siswa atau 22,2\% pada ketegori "tinggi", sedangkan 0 persen pada kategori sangat tinggi, rendah, dan sangat rendah, jika nilai rata-rata hasil belajar dikonversikan kedalam lima kategori diatas termaksud kategori sedang.

Tabel 4.3 Persentase Ketuntasan Klasikal Belajar Siswa Kelas XI IPS 1 SMA Negeri 12 Makassar pada Nilai Hasil Belajar siswa Pretes

\begin{tabular}{clcc}
\hline $\begin{array}{c}\text { Nilai } \\
\text { KKM }\end{array}$ & Kategori & Frekuensi & Persentase \\
\hline$<75$ & Tidak Tuntas & 22 & \\
$<75$ & Tuntas & 13 & $62,86 \%$ \\
& & & $37,14 \%$ \\
\hline
\end{tabular}


email: lageografia@unm.ac.id

Jurusan Geografi Fakultas Matematika dan Ilmu Pengetahuan Alam

Universitas Negeri Makassar Sulawesi Selatan, Indonesia

Nisaa, Baiatun, 2017, Penerapan Model Pembelajaran Problem Based Learning (Pbl) Untuk Meningkatkan Hasil Belajar Geografi Kelas XI Ips 1 SMA Negeri 12 Makassar.

Sumber: Hasil Olahan Data, 2017

Tabel diatas menunjukkan bahwa hasil belajar siswa kelas XI IPS 1 sebelum menggunakan model problem based learning (pretes) ditemukan terdapat 62,86\% siswa yang belum tuntas secara klasikal karena terdapat 22 siswa yang belum mencapai nilai 75, nilai KKM pada mata pelajaran geografi dan terdapat 13 siswa atau 37,14\% siswa yang tuntas belajar secara klasikal.

\section{Hasil penelitian pada siklus I}

Siklus 1 terdiri dari empat tahap, yakni perencanaan, pelaksanaan, observasi dan evaluasi serta refleksi dengan perencanaan pertemuan 1 dan 2 pemberian materi dan pertemuan 3 tes akhir siklus.

\section{a. Hasil Belajar Siklus 1}

Siklus I dilaksanakan tes hasil belajar siswa untuk mengetahui sejauh mana pemahaman siswa mengenai materi yang diberikan, tes evaluasi siklus I berbentuk soal pilihan ganda 25 nomor. Berikut nilai hasil belajar postes siklus I yang diberikan pada siswa kelas XI IPS 1 SMA Negeri 12 Makassar dengan materi kependudukan dengan penerapan Model Problem Based Learning dapat dilihat pada tabel berikut ini:

Tabel 4.4 Distribusi Nilai Hasil Belajar Geografi siswa kelas XI IPS 1 SMA Negeri 12 Makassar pada Siklus I

\begin{tabular}{cc}
\hline Data Penelitian & Nilai Statistik \\
\hline Subjek & 35 \\
Skor Ideal & 100 \\
Nilai Terendah & 56,67 \\
Nilai Tertinggi & 83,33 \\
Rentang Skor & 26,66 \\
Rata-rata Skor & 73,81 \\
\hline
\end{tabular}

Sumber: Hasil Olahan Data, 2017

Tabel 4.4 diperlihatkan bahwa rata-rata hasil belajar geografi siswa pada siklus I dengan materi ajar resiko kependudukan dengan penerapan nodel problem based learning adalah $73,81 \%$ dari skor ideal 100 yang mungkin dicapai oleh siswa. Skor yang dicapai oleh siswa tersebar dari skor terendah 56,67\% sampai dengan skor tertinggi 83,33\% dengan rentang skor yang diperoleh 26,66\%. Karena nilai rentang skor yang diperoleh besar, maka tingkat keragaman data besar pula, ini mengakibatkan nilai-nilai yang diperoleh siswa saling berjahuan. Jika skor hasil belajar geografi siswa dikelompokkan ke dalam lima kategori maka diperoleh distribusi frekuensi dan persenase sebagai berikut:

Tabel 4.5 Distribusi Frekuensi dan persentase ketegori Hasil Belajar pada Siklus I

\begin{tabular}{|c|c|c|c|c|}
\hline No & Skor & Kategori & Frekuensi & Persentase \\
\hline 1. & $<55$ & Sangat Rendah & 3 & $8,57 \%$ \\
\hline 2 & $55-59$ & Rendah & 1 & $2,85 \%$ \\
\hline 3. & $60-75$ & Sedang & 12 & $34,2 \%$ \\
\hline 4. & $76-85$ & Tinggi & 19 & $54,28 \%$ \\
\hline 5. & $86-100$ & Sangat Tinggi & 0 & 0 \\
\hline \multicolumn{3}{|c|}{ Jumlah } & 35 & $100 \%$ \\
\hline
\end{tabular}

Sumber: Hasil Olahan Data, 2017

Tabel 4.5 menunjukkan bahwa dari 35 siswa skor hasil belajar geografi cukup bervariasi. Jika skor rata-rata hasil belajar siswa sebesar $73,81 \%$ dikonversikan ke dalam lima kategori 
ISSN:1412-8187

email: lageografia@unm.ac.id

Jurusan Geografi Fakultas Matematika dan Ilmu Pengetahuan Alam

Universitas Negeri Makassar Sulawesi Selatan, Indonesia

Nisaa, Baiatun, 2017, Penerapan Model Pembelajaran Problem Based Learning (Pbl) Untuk Meningkatkan Hasil Belajar Geografi Kelas XI Ips 1 SMA Negeri 12 Makassar.

diatas, maka skor rata-rata hasil belajar siswa kelas XI IPS 1 SMA Negeri 12 Makassar pada siklus I dengan kategori "Tinggi"

Selanjutnya hasil belajar geografi siswa pada siklus I dianalisis maka persentase ketuntasan klasifikal belajar siswa pada siklus I dapat dilihat pada tabel berikut:

Tabel 4.6 Persentase Ketuntasan Klasifikasi Belajar Siswa Kelas XI IPS 1 SMA Negeri 12 Makassar pada Siklus I

\begin{tabular}{cccc}
\hline Nilai & Kategori & Frekuensi & Persentase \\
KKM & & & \\
\hline$<75$ & Tidak Tuntas & 16 & 45,71 \\
$<75$ & Tuntas & 19 & 54,28 \\
\hline
\end{tabular}

Sumber: Hasil Olahan Data, 2017

Tabel 4.6 di atas menunjukkan bahwa 16 siswa atau 45,71\% dari 35 siswa termaksuk dalam kategori tidak tuntas karena belum mencapai nilai KKM dan terdapat 19 siswa atau 54,28\% yang termaksuk dalam kategori tuntas. Hal ini berarti terdapat $45,71 \%$ siswa yang memerlukan perbaikan karena belum mencapai kriteria ketuntasan individual dan akan di usahakan pada pembelajaran selanjutnya di siklus II.

\section{b. Aktivitas Siswa Siklus I}

Aktivitas siswa selama proses pembelajaran berlangsung pada siklus I dengan menerapkan Model problem based learning dapat diliat pada lembar observasi aktivitas belajar siswa dilama observasi pada setiap pertemuan yang diamati dan di isi oleh guru mata pelajaran geografi selaku observer pada saat proses mengajar berlangsung dikelas

\section{c. Refleksi siklus I}

\section{Refleksi pertemuan pertama}

Berdasarkan tindakan pada siklus I upaya untuk meningkatkan prestasi belajar siswa melalui penerapan model pembelajaran PBL masih belum menunjukkan hasil yang maksimal. Adapun masalah-masalah yang dihadapi antara lain:

Refleksi pertemuan pertama:

a. Masih terdapat siswa yang kurang antusias saat pembelajaran berlangsung

b. Aktivitas siswa dalam mengikuti kegiatan belajar sebagian besar masih pasif.

c. Masih banyak siswa yang belum berani menjawab pertanyaan yang dilontarkan oleh guru.

d. Masih banyak siswa yang belum berani mengemukakan pendapatnya

e. Kerjasama dan keaktivan siswa dalam kelompok perlu lebih ditingkatkan.

f. Masih terdapat beberapa siswa yang tidak memperhatikan dan memusatkan perhatiannya pada pelaksanaan diskusi

g. Masih terdapat siswa yang belum mampu menyimpulkan materi yang dibahas dalam proses pembelajaran

\section{Refleksi pertemuan kedua}

a. Masih terdapat siswa yang kurang antusias saat pembelajaran berlangsung

b. Aktivitas siswa dalam mengikuti kegiatan belajar sebagian besar masih pasif.

c. Masih banyak siswa yang belum berani menjawab pertanyaan yang dilontarkan oleh guru.

d. Masih banyak siswa yang belum berani mengemukakan pendapatnya

e. Kerjasama dan keaktivan siswa dalam kelompok perlu lebih ditingkatkan. 
email: lageografia@unm.ac.id

Jurusan Geografi Fakultas Matematika dan Ilmu Pengetahuan Alam

Universitas Negeri Makassar Sulawesi Selatan, Indonesia

Nisaa, Baiatun, 2017, Penerapan Model Pembelajaran Problem Based Learning (Pbl) Untuk Meningkatkan Hasil Belajar Geografi Kelas XI Ips 1 SMA Negeri 12 Makassar.

f. Masih terdapat beberapa siswa yang tidak memperhatikan dan memusatkan perhatiannya pada pelaksanaan diskusi

g. Masih terdapat siswa yang belum mampu menyimpulkan materi yang dibahas dalam proses pembelajaran

Pelaksanaan Siklus I ini masih terdapat beberapa kendala yang dihadapi oleh penulis perutama pada pertemuan pertama siswa kurang aktif dimana siswa tidak mendengarkan guru dan banyak aktivitas lain yang dikerjadalam proses belajar mengajar, beberapa siswa setelah diabsen keluar dari kelas mareka beranggapan bahwa pelajaran geografi sangat membosankan, pada saat pembentukan kelompok mereka cenderung rebut dalam diskusi kelompok pun masih banyak siswa yang kurang aktif dan melakukan aktivitas lain pada saat proses diskusi berlangsung, yang berperan hanyalah beberapa orang sja pada setiap kelompok ini disebabkan karena jumlah kelompok pada siklus I terdapat 6 kelompok masing-masing kelompok beranggotakan 6 siswa sehingga siswa tidak semua berperan aktif dalam mengerjakan lembar kerja kelompoknya yang telah di bagikan ini menimbulkan tidak terlaksananya kerja kelompok dengan baik, pada saat persentase hasil yang berperan hanyalah kelompok diskusi yang menyajikan materinya. Selanjutnya pada pertemuan ke dua siswa diberi penguatan oleh guru/peneliti mereka akhirnya perlahan mulai menyenangi materi yang yang diajarkan, walaupun pada pertemuan siklus I keaktifan siswa termasuk kategori cukup tapi setidaknya siswa sudah mulai menyenangi pelajaran.

Dalam proses belajar mengajar, kemampuan siswa dalam mengkontruksi masih rendah. Hal ini terlihat dari siswa hanya cenderung menerima bukan memecahkan masalah dan mengkonstruksi pengetahuan benak mereka. Hasil pengamatan dari lembar observasi pada siklus I belum maksimal karena dalam proses belajar aktivitas siswa masih kurang (Tabel 4.6), yaitu pembelajaran kelompok siswa masih kurang aktif dalam mengerjakan tugas kelompoknya sehingga pada saat diskusi berlangsung siswa kurang fokus mengikuti jalannya diskusi dan tidak bersemangat dalam mengajukan Tanya jawab. Pada saat akhir pelajaran siswa diberikan LKS yang megarahkan siswa untuk bekerja secara individu tapi masih ada yang bekerja sama dengan temannya namun setelah pertemuan berikutnya hal ini menunjukkan peningkatan tetapi belum maksimal sampai pada akhir siklus ini.

Demikian pula model problem based learning yang diterapkan. Pada materi awal pertemuan belum menunjukkan kekompakan kerjasama sekolompok dalam memecahkan suatu masalah, sampai pada akhir pertemuan, namun di siklus ini mengalami peningkatan nilai hasil belajar yang sebelumnya nilai rata-rata hasil belajar tengah semester 71,34\% setelah diterapkan Model problem based learning menjadi 73,81\%, namun aktivitas dalam proses pembelajaran belum maksimal dan akan ditingkatkan pada siklus berikutnya:

Setiap akhir pembelajaran pada tiap pertemuan senantiasa diberikan refleksi terhadap materi yaitu menyimpulkan materi yang telah di berikan pada pertemuan tersebut. Hal ini menunjukkan hanya beberapa siswa sudah mampu menyimpulkan materi meskipun dalam penyempurnaannya masih sering dibantu oleh penulis sebagai guru mata pelajaran.

Pada akhir siklus I yakni pertemuan ketiga dilaksanakan ujian siklus I mereka menunjukkan kesiapan dalam ujian. Hal ini terlihat ketika soal-soal dibagikan mereka cukup tenang dan mereka mengerjakan dengan penuh semangat meskipun masih ada yang merasa sulit karena tidak belajar. Selain itu ada pula yang mencontoh pekerjaan temannya. Namun hal ini dapat diatasi dengan memberikan penegasan kepada siswa serta lebih memperketat pengawasan.

Secara umum siswa menyenangi perjalanan geografi dengan menerapkan Model problem based learning karena materi yang disajikan kepada siswa senantiasa berkaitan dengan 
email: lageografia@unm.ac.id

Jurusan Geografi Fakultas Matematika dan Ilmu Pengetahuan Alam

Universitas Negeri Makassar Sulawesi Selatan, Indonesia

Nisaa, Baiatun, 2017, Penerapan Model Pembelajaran Problem Based Learning (Pbl) Untuk Meningkatkan Hasil Belajar Geografi Kelas XI Ips 1 SMA Negeri 12 Makassar.

situasi nyata dalam kehidupan sehari-hari, menyenangkan dan bermakna. Meskipun masih ada beberapa siswa yang passif.

\section{Hasil peneliatian pada siklus II}

Pelaksanaan tindakan dalam siklus II ini adalah pengulangan langkah kerja pada siklus sebelumnya yang telah mengalami berbaikan dan pengembangan yang disesuaikan dengan hasil refleksi dari siklus I. kegiatan-kegiatan dalam siklus ini diulangi secara bertahap yang mungkin terjadi, dimana tiap siklus tersebut adalah perbaikan dari siklus sebelumnya, dengan rincian pertemuan 4 dan 5 pemberian materi dan pertemuan 6 evaluasi akhir siklus II.

\section{a. Hasil belajar siklus II}

Hasil belajar siswa kelas XI IPS 1 SMA Negeri 12 Makassar pada materi ajar kependudukan dengan menerapkan Model Problem Based Learning pada siklus II merupakan pengulangan dari siklus I baik dari segi perencanaan, tindakan, observasi dan evaluasi serta refleksi sesuai keadaan yang ditemukan pada siklus I. hasil permasalahan yang belum tuntas pada siklus I diselesaikan pada siklus II dengan materi yang belum diajarkan dengan menambahkan media yang lebih detail. Berikut tabel distribusi nilai hasil belajar setelah penerapan model problem based learning:

Tabel 4.7 Distribusi nilai Hasil Belajar Geografi siswa kelas XI IPS 1 SMA Negeri 12 Makassar pada Siklus II

\begin{tabular}{cc}
\hline Data Penelitian & Nilai Statistik \\
\hline Subjek & 35 \\
Skor Ideal & 100 \\
Nilai Terendah & 70 \\
Nilai Tertinggi & 90 \\
Rentang Skor & 20 \\
Rata-rata Skor & 79,01 \\
\hline
\end{tabular}

Sumber: Hasil Olahan Data, 2017

Tabel 4.7 terdapat 35 subjek dengan rata-rata hasil belajar geografi siswa pada siklus II pada materi kependudukan dengan penerapan Model problem based learning adalah 79,01 dengan nilai yang dicapai oleh siswa tersebar dari skor terendah 70 sampai dengan skor tertinggi 90 dengan rentang skor yang diperoleh 20. Karena nilai rentang skor yang diperoleh besar, maka tingkat keragaman data besar pula, ini mengakibatkan nilai-nilai yang diperoleh siswa saling berjauhan.

Tabel 4.8 Distribusi Frekuensi dan Persentase kategori Hasil Belajar pada Siklus II

\begin{tabular}{|c|c|c|c|c|}
\hline No & Skor & Kategori & Frekuensi & Persentase \\
\hline 1. & $<55$ & Sangat Rendah & 0 & 0 \\
\hline 2 & $55-59$ & Rendah & 0 & 0 \\
\hline 3. & $60-75$ & Sedang & 4 & $11,42 \%$ \\
\hline 4. & $76-85$ & Tinggi & 30 & 85,71 \\
\hline 5. & $86-100$ & Sangat Tinggi & 1 & 2,85 \\
\hline \multicolumn{3}{|c|}{ Jumlah } & 35 & $100 \%$ \\
\hline
\end{tabular}

Sumber: Hasil Olahan Data, 2017

Tabel 4.8 menunjukkan bahwa dari 35 siswa nilai hasil belajar geografi hampir sama. Jika nilai rata-rata hasil belajar siswa sebesar 79,01\% dikonversikan ke dalam lima kategori diatas, 
ISSN:1412-8187

email: lageografia@unm.ac.id

Jurusan Geografi Fakultas Matematika dan Ilmu Pengetahuan Alam

Universitas Negeri Makassar Sulawesi Selatan, Indonesia

Nisaa, Baiatun, 2017, Penerapan Model Pembelajaran Problem Based Learning (Pbl) Untuk Meningkatkan Hasil Belajar Geografi Kelas XI Ips 1 SMA Negeri 12 Makassar.

maka nilai rata-rata hasil belajar siswa kelas XI IPS 1 SMA Negeri 12 Makassar pada siklus II dalam karegori "tinggi

Selanjutnya nilai hasil belajar geografi siswa pada siklus II dianalisis maka persentase ketuntasan klasikal belajar siswa pada siklus II dapat dilihat pada tabel berikut:

Tabel 4.9 Persentase Ketuntasan klasikal Belajar Siswa Kelas XI IPS 1 SMA Negeri 12

Makassar

\begin{tabular}{cccc}
\hline Nilai & Kategori & Frekuensi & Persentase \\
KKM & & & \\
\hline$<75$ & Tidak Tuntas & 4 & 11,42 \\
$<75$ & Tuntas & 31 & 88,54 \\
\hline
\end{tabular}

Sumber: Hasil Olahan Data, 2017

Tabel 4.9 menunjukkan terdapat 4 siswa atau $11,42 \%$ dari 35 siswa termaksuk dalam kategori tidak tuntas dan terdapat 31 siswa atau $88,54 \%$ yang termasuk dalam kategori tuntas. Hal ini menunjukkan bahwa terjadi peningkatan hasil belajar dari siklus I ke Siklus II, dimana persentase ketuntasan hasil belajar secara klasikal yang mengalami perubahan walaupun dalam siklus II hasih terdapat $11,42 \%$ siswa yang tidak tuntas secara klasikal namun ini menunjukkan terdapat perbaikan dalam menyerap materi yang diajarkan melalui penerapan model pembelajaran Problem Based Learning, sehingga tidak perlu lagi dilanjutkan ke siklus selanjutnya.

Selanjutnya diperlihatkan peningkatan hasil belajar siswa sebelum diterapkan Model problem based learning (pretes) dan setelah diterapkan model problem based learning pada materi ajar sumber data kependudukan dan kuantitas dan analisis demografi (materi siklus I) serta mobilitas penduduk dan pengendaliannya serta permasalahan kependudukan dan solusinya (materi siklus II) yang dapat dilihat pada tabel berikut ini:

Berdasarkan hasil deskriptif dari nilai rata-rata sebelum dan setelah menerapkan Model problem based learning pada siklus I dan siklus II diatas menunjukkan bahwa persentase peningkatan hasil belajar siswa adalah 6,58\%.

Berikut diperlihatkan gambar diagram peningkatan hasil belajar geografi siswa kelas XI IPS 1 sebelum dan setelah penerapan model pembelajaran problem based learning:

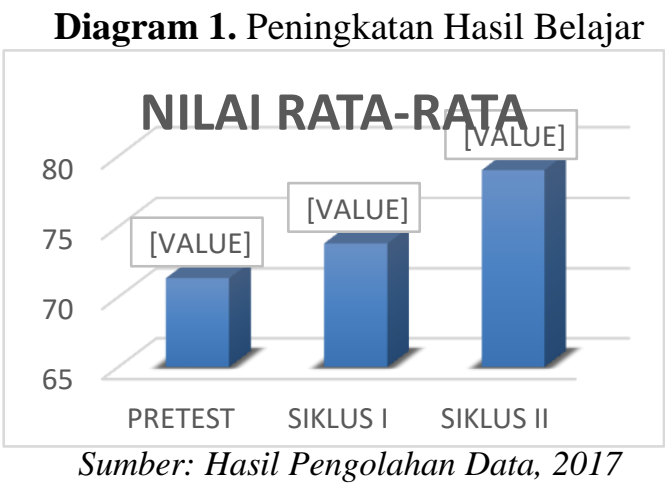

Diagram diatas menunjukkan terjadi peningkatan hasil belajar sebelum dan sesudah penerapan model pembelajaran problem based learning terlihat rata-rata dari pretes yakni 71,34\% mengalami perubahan pada siklus I yakni 73,81 Dan pada siklus II yakni 79,01\% dengan persentase peningkatan adalah $6,58 \%$.

\section{b. Aktivitas siswa siklus II}


email: lageografia@unm.ac.id

Jurusan Geografi Fakultas Matematika dan Ilmu Pengetahuan Alam

Universitas Negeri Makassar Sulawesi Selatan, Indonesia

Nisaa, Baiatun, 2017, Penerapan Model Pembelajaran Problem Based Learning (Pbl) Untuk Meningkatkan Hasil Belajar Geografi Kelas XI Ips 1 SMA Negeri 12 Makassar.

Selama penelitian berlangsung, terjadi perubahan sikap dalam proses belajar mengajar siklus I ke siklus II tercatat sejumlah perubahan yang terjadi pada setiap siswa terhadap pelajaran geografi. Perubahan tersebut diperoleh dari lembar observasi aktivitas belajar siswa yang di isi oleh guru mata pelajaran geografi selaku observer pada setiap pertemuan yang dicatat pada setiap siklus pada lembar kerja observasi tersebut. Untuk mengetahui perubahan sikap siswa selama proses belajar mengajar berlangsung di kelas.

\section{Pembahasan}

Hasil analisis deskriptif menunjukkan bahwa nilai rata-rata hasil belajar geografi tengah semester (pretes) 71,34\% dengan ketuntasan secara klasikal 37,14\%, mengalami perubahan setelah menerapkan model problem based learning (PBL) pada materi ajar sumber data kependudukan dan kuantitas dan analisis demografi yaitu pada siklus I diperoleh nilai rata-rata $73,81 \%$ dari nilai rata-rata yang mungkin tercapai yaitu 100. Siswa yang memperoleh ketuntasan belajar secara klasikal pada Siklus I 54,28\%. Dari segi ketuntasan hasil belajar siswa secara klasikal pasa Siklus I ini menunjukkan belum tuntas dikarenakan masih ada 45,71\% siswa yang belum memperoleh nilai yang diharapkan sesuai KKM geografi yang diterapkan di SMA Negeri 12 Makassar.

Sementara itu hasilbelajar geografi pada materi ajar pembangunan berkelanjutan dan tindakan-tindakan pelestarian lingkungan hidup pada Siklus II dengan menerapkan model problem based learning (PBL) diperoleh nilai rata-rata sebesar79,01 dari siswa yang memperoleh ketuntasan belajar secara klasikal 88,54 persen. Terjadi peningkatan dari nilai ratarata hasil belajar siswa sebelum dan setelah diterapkan Model problem based learning sebanyak 6,58\%. Ditinjau dari segi ketuntasan individu juga terjadi peningkatan yaitu 54,28\% menjadi $79,01 \%$. Namun secara klasikal baik pada siklus I maupun pada siklus II masih ada beberapa siswa yang secara individu belum tuntas hasil belajarnya menyatakan bahwa kemampuan dasar mereka sangat kurang dalam menyerap materi dan malas mengerjakan tugas yang diberikan serta absen atau jarang masuk pada saat belajar geografi berlangsung. Dari pertanyaan itulah maka dapat disimpulkan bahwa hal ini mempengaruhi ketuntasan hasil belajar siswa baik secara individu maupun secara klasikal.

Selain dalam peningkatan hasil belajar siswa dari siklus ke siklus, peningkatan aktivitas belajar siswa dalam proses pembelajaran mengalami perubahan yang tidak lepas dari motivasi dan perhatian siswa, menunjukkan perubahan yang lebih baik dari sebelumnya, seperti terlihat pada tabel 4.8

Berdasarkan hasil analisis kualitatif dari lembar observasi aktivitas siswa mengalami peningkatan dari Siklus I ke Siklus II. Dimana pada siklus I siswa kurang aktif dalam mengikuti pelajaran dan banyak melakukan aktivitas lain, terlibat dalam kerja kelompok, kurang aktif menjawab dan mengajukan pertanyaan dengan persentase keaktifan dengan kategori kurang aktif menglami perubahan sikap pada siklus II dengan kategori aktif, peningkatan ini terlihat ketika siswa terlibat aktif diskusi, berkejasama baik dengan kelompoknya, terlibat dalam Tanya jawab pada saat diskusi, serta mampu menyimpulkan materi yang dibahas. Ini menunjukkan bahwa model problem based learning memberikan dampak positif karena mampu meningkatkan hasil belajar siswa dan aktivitas dalam proses belajar mengajar berlangsung. 
email: lageografia@unm.ac.id

Jurusan Geografi Fakultas Matematika dan Ilmu Pengetahuan Alam

Universitas Negeri Makassar Sulawesi Selatan, Indonesia

Nisaa, Baiatun, 2017, Penerapan Model Pembelajaran Problem Based Learning (Pbl) Untuk Meningkatkan Hasil Belajar Geografi Kelas XI Ips 1 SMA Negeri 12 Makassar.

\section{KESIMPULAN DAN SARAN}

\section{Kesimpulan}

Berdasarkan tujuan penelitian dan pembahasan maka dapat disimpulkan bahwa hasil belajar geografi siswa kelas XI IPS 1 SMA Negeri 12 Makassar mengalami peningkatan setelah diterapkan Model problem based learning dengan indikasi sebagai berikut:

1. Nilai rerata belajar hasil geografi siswa siswa dimana sebelum menggunakan model pembelajaran problem based learning 71,34\% mengalami peningkatan setelah diterapkan model problem based learning pada siklus I $73,81 \%$ termasuk kategori sedang dan siklus II $79,01 \%$ termasuk kategori tinggi, dengan persentase peningkatan $6,58 \%$.

2. Hasil observasi aktivitas siswa dalam kegiatan belajar mengajar mengalami perubahan, pada siklus I 46,7\% mengalami perubahan aktivitas belajar siswa pada siklus II 59,4\% dengan kategori aktif. Hal ini berarti mengalami perbaikan sikap dari siklus sebelumnya.

\section{Saran}

Berdasarkan hasil yang diperoleh dari penelitian ini, maka penulis mengajukan beberapa saran sebagai berikut:

1. Kepada guru geografi khususnya, kiranya dapat mencoba menerapkan Model Problem Based learning dalam proses belajar mengajar agar dapat meningkatkan hasil belajar siswa.

2. Guru geografi sebaiknya kreatif dalam menciptakan suasana kelas agar siswa tidak bosan dan nyaman dalam penyajian materi pada saat belajar serta lebih termotivasi dalam memperhatikan apa yang diajarkan.

3. Sebaiknya kepada pihak sekolah memaksimalkan sarana dan prasarana di sekolah, menyediakan buku ajar di perpustakaan, sehingga siswa yang tidak memiliki buku pelajaran dapat meminjam di perpustakaan

4. Diharapkan kepada peneliti yang akan melakukan penelitian sebaiknya mengambil satu permasalahan misalnya kombinasi antara Model Problem based learning ini dengan salah satu metode pembelajaran, untuk mengetahui lebih lanjut apakah dengan penerapan dapat meningkatkan hasil belajar siswa yang lebih baik lagi.

\section{DAFTAR RUJUKAN}

Arikunto, Suharsimi. 2008. Penelitian Tindakan Kelas. Bandung: Bumi Aksara

Arikunto, Suharsimi. 2009. Dasar-dasar evaluasi pendidikan (edisi revisi). Jakarta: Bumi Aksara

Sanjaya. (2014). Strategi Pembelajaran berorientasi Standar Proses Pendidikan. Jakarta:

Kencana Prenada Media Group

Slameto. 2003. Belajar dan Faktor-faktor yang Mempengaruhinya. Jakarta: Rineka Cipta.

Slameto. 2010. Belajar dan Faktor-faktor yang Mempengaruhinya. Edisi Revisi. Jakarta:

Rineka Cipta.

Slavin. (2013). Desain Belajar Mengajar Kreatif Berbasis Sains. Bangunntapan Jogjakarta: DIVA Pres

Sobur, Alex. 2003. Psikologi Umum. Bandung: Pustaka Setia.

Sugiyono, Prof Dr. 2013. Metode Penelitian Pendidikan pendekatan Kuantitatif, Kualitatif, dan $R \& D$. Bandung; Alfabeta. 
ISSN:1412-8187

email: lageografia@unm.ac.id

Jurusan Geografi Fakultas Matematika dan Ilmu Pengetahuan Alam

Universitas Negeri Makassar Sulawesi Selatan, Indonesia

Nisaa, Baiatun, 2017, Penerapan Model Pembelajaran Problem Based Learning (Pbl) Untuk Meningkatkan Hasil Belajar Geografi Kelas XI Ips 1 SMA Negeri 12 Makassar.

Suprijono, A. 2011. Coomperative Learning Teri and Aplikasi Pakem. Yogyakarta: Purtaka Belajar.

Trianto. 2009. Mendesain Model Pembelajaran Inovatif-Progresif. Jakarta: Kencana Prenada Media Group.

\section{Editor In Chief}

\section{Erman Syarif}

emankgiman@unm.ac.id

\section{Publisher}

Geography Education, Geography Departemenr, Universitas Negeri Makassar

Ruang Publikasi Lt.1 Jurusan Geografi Kampus UNM Parangtambung, Jalan Daeng Tata, Makassar.

Email : lageografia@unm.ac.id

Info Berlangganan Jurnal 085298749260 / Alief Saputro 